\title{
ALDEAMENTOS JESUÍTAS E POLÍTICA COLONIAL NA BAHIA, SÉCULO XVIII
}

\author{
Fabricio Lyrio Santos
}

Universidade Federal do Recôncavo da Bahia

\section{Resumo}

$\mathrm{O}$ artigo enfoca a questão dos aldeamentos missionários dirigidos pelos jesuítas na Bahia durante o período colonial e sua transformação em vilas na segunda metade do século XVIII. A análise da documentação revela uma preocupação excessiva do Estado português com o aparato político e econômico estabelecido pelas ordens religiosas missionárias entre as populações indígenas, ao longo de dois séculos de catequese e domínio.

\section{Palavras-Chave}

Jesuítas • Populações Indígenas • Política colonial

\section{Abstract}

This article is about the Indian missions organized by the Jesuits in Bahia during the colonial period and its transformation on villages at the second half of 18th century. The analysis of the documents indicates a special attention of the Portuguese government with the economic and political organization controlled by the missionary orders, along two centuries of catechesis and domination.

\section{Keywords}

Jesuits • Indians • Colonial Policy

\footnotetext{
*Este artigo é uma versão ligeiramente modificada de uma comunicação com este mesmo título apresentada no VIII Simpósio Nacional da Associação Brasileira de História das Religiões e Colóquio do Centenário da Morte de Nina Rodrigues, realizado entre os dias 2 5 de maio de 2006 na Universidade Federal do Maranhão.
} 
Com certeza, o Estado cristão aprimorado não é o chamado Estado cristão que admite o cristianismo como seu alicerce, como a religião de Estado, adotando, consequentemente, uma atitude de eliminação perante as outras religiões; é antes o Estado ateu, o Estado democrático, o Estado que relega a religião para o meio, os outros elementos da sociedade civil.

Karl Marx. A questão judaica.

Em seu clássico Casa Grande e Senzala, Gilberto Freyre defende que os jesuítas contribuíram para dispersar, através da catequese e dos aldeamentos, a unidade que eles próprios articulavam através de seu sistema moral e educacional ${ }^{1}$. O grande erro da empresa inaciana teria sido a segregação religiosa dos índios nas aldeias. O controle sobre as populações indígenas teria levado os jesuítas ao mercantilismo e ao escravagismo, explorando o trabalho indígena em proveito próprio ${ }^{2}$. Em Formação do Brasil Contemporâneo, Caio Prado Jr. defende tese semelhante, argumentando que os aldeamentos, traçados a partir dos interesses específicos defendidos pela Igreja no âmbito da empresa colonial, segregavam a população indígena e impediam o índio de se tornar elemento ativo na sociedade, "participante integrado na vida colonial" . A idéia de que os aldeamentos teriam se tornado "coletividades enquistadas" no seio da civilização colonial reproduz, sem dúvida, a opinião de Capistrano de Abreu, para quem "as aldeias tornaram-se não só um estado no estado como uma igreja na igreja"4.

Poderíamos questionar, entretanto, se os aldeamentos não teriam servido de algum modo para consolidar os interesses do Estado português nas terras coloniais e expandir as fronteiras da ocupação luso-brasileira, uma vez que a própria configuração política do Império lusitano apoiava-se, desde o início, em uma profunda indissociabilidade entre o poder político e o religioso. Num

\footnotetext{
${ }^{1}$ FREYRE, Gilberto. Casa-Grande e Senzala. Formação da família brasileira sob o regime da economia patriarcal. In : Intérpretes do Brasil. 2 ed. Rio de Janeiro : Nova Aguilar, 2002, vol. 2, p. 174.

${ }^{2}$ Ibid., p. 284-285.

${ }^{3}$ PRADO JR., Caio. Formação do Brasil contemporâneo : Colônia. In : Intérpretes do Brasil. 2 ed. Rio de Janeiro : Nova Aguilar, 2002, vol. 3, p. 1197.

${ }^{4}$ Ibid., p. 1198; ABREU, João Capistrano de. Capítulos de história colonial (1500-1800). Rio de Janeiro : Sociedade Capistrano de Abreu, 1936, p. 164.
} 
momento em que o Rei e o Papa convergiam em propósitos e alimentavam a expectativa de um "êxito compartilhado", o regime de padroado revelava-se como expressão formal ou jurídica do reconhecimento de uma perfeita "simbiose do espiritual e do temporal" . Podemos afirmar que o trabalho missionário já nasceu comprometido com a ordem política e social da colônia em formação, sem contradizer os interesses políticos ou mercantis mais amplos. Ao criar uma zona privilegiada de contato entre a cultura européia e as diferentes culturas indígenas, os jesuítas possibilitaram o efetivo avanço da colonização lusitana nas terras americanas.

O início deste trabalho missionário na Bahia concentrou-se ao redor do sítio fundador da cidade de Salvador, sede do governo geral, fora das paliçadas construídas por Thomé de Souza em 1549. Os missionários deslocavam-se para os povoados indígenas existentes nos arredores da cidade na tentativa de converter os índios pela palavra e ensinar-lhes a doutrina ${ }^{6}$. Os poucos que iam chegando ao Brasil neste período dividiam-se para dar conta do trabalho missionário na Bahia e nas demais capitanias. Aos poucos, o sistema de evangelizar aldeias circunvizinhas às povoações portuguesas se reproduziu nas principais vilas que iam sendo estabelecidas pelos colonos, constituindo um movimento denominado por Hoornaert de "ciclo missionário litorâneo"7.

Os jesuítas encontraram grandes aliados em Thomé de Souza e Mem de Sá, primeiro e terceiro governadores gerais ${ }^{8}$. Logo se tornaria evidente para os missionários que a intervenção do poder civil constituía um importante aliado do trabalho destes, na medida em que o castigo aos índios relutantes e hostis servia de exemplo para que os demais aceitassem prontamente se submeter à nova fé e civilização propostas?.

\footnotetext{
${ }^{5}$ SILVA, Cândido da Costa e. Os segadores e a messe : o clero oitocentista na Bahia. Salvador: SCI; EDUFBA, 2000, p. 25.

${ }^{6}$ LEITE, Serafim. História da Companhia de Jesus no Brasil, Rio de Janeiro : Instituto Nacional do Livro, 1938-1950, t. II, p. 46. Sendo ele próprio jesuíta, Leite produziu a "história oficial" da ordem inaciana em terras brasileiras. Não obstante, conseguiu imprimir um valor insubstituível à sua obra em função do imenso volume de informações e fontes primárias que reuniu.

${ }^{7}$ HOORNAERT, Eduardo et al. História da Igreja no Brasil : ensaio de interpretação a partir do povo. Primeira época. 4. ed. Petrópolis : Vozes, 1992. Esta obra representa um marco nos estudos da história da igreja no Brasil por ter sido uma primeira tentativa de síntese ancorada em uma perspectiva não confessional, embora seus próprios autores fossem ligados à Igreja.

${ }^{8}$ LEITE, História da Companhia de Jesus no Brasil, t. II, p. 143-150.

${ }^{9}$ EISENBERG, José. As missões jesuíticas e o pensamento político moderno : encontros culturais, aventuras teóricas. Belo Horizonte : Editora UFMG, 2000.
} 
O fracasso da primeira experiência missionária deveu-se, em parte, à própria organização social dos principais grupos indígenas que habitavam o litoral. As guerras intertribais e o sacrifício dos prisioneiros em rituais antropofágicos, tanto quanto os costumes associados ao corpo e à sexualidade, criavam sérios obstáculos à implantação da religião cristã e dos costumes europeus. Mas o principal entrave para a realização do trabalho missionário nas aldeias era sua mobilidade geográfica. Os grupos litorâneos realizavam migrações periódicas buscando a ocupação de áreas consideradas mais férteis e ricas de recursos, quebrando a rotina de catequese :

Se os Padres se contentassem com percorrer as aldeias indígenas, além dos possíveis riscos, tirariam precário fruto. O que ensinavam um mês, por falta de exercício e de exemplo, estiolaria no outro. Quantas vezes, com o nomadismo intermitente dos Índios, ao voltarem os Padres a uma povoação, que deixaram animada pouco antes, em lugar dela achavam cinza! $!^{10}$.

A tentativa de superação desta primeira experiência missionária se deu através do plano de catequese elaborado pelo padre Manoel da Nóbrega, no qual propunha a criação de aldeias ou reduções indígenas onde a população de diferentes povoados nativos seria reunida, pelos próprios missionários (com o auxílio do Estado), objetivando submetê-los a uma rotina permanente de aprendizado dos ensinamentos cristãos: "antecipando o modelo das reducciones paraguaias, o novo plano dos jesuítas previa que os índios seriam forçados a viver de acordo com a cultura cristã para subsequentemente serem persuadidos a se converterem à religião de Cristo"11. Como afirma Baêta Neves, por meio de uma experiência de "socialização prolongada", a aldeia tornava-se "um grande projeto pedagógico total" $"$.

Os aldeamentos visavam, sobretudo, a sedentarização das populações indígenas, propiciando um maior controle sobre suas práticas culturais e possibili-

\footnotetext{
${ }^{10}$ LEITE, História da Companhia de Jesus no Brasil, t. II, p. 42. A opinião de Leite reflete a visão de seus próprios confrades do século XVI, segundo registrado em suas numerosas cartas. Ficará evidente depois que a sedentarização forçada dos índios não era garantia de sua conversão ou civilização.

${ }^{11}$ EISENBERG, As missões jesuíticas e o pensamento político moderno, p. 21.

${ }^{12}$ NEVES, Luis Felipe Baêta. O Combate dos soldados de Cristo na terra dos papagaios. Rio de Janeiro : Forense-Universitária, 1978, p. 162.
} 
tando o rompimento com tudo aquilo que fosse visto pelos missionários como oposto ao cristianismo : "Para que houvesse uma transformação de costumes a destribalização se fazia necessária, e, mais do que a destribalização o rompimento com as antigas tradições" ${ }^{13}$. Como afirma Leite,

(...) a catequese seria uma quimera, enquanto se não organizassem Aldeias, com regime próprio de defesa e autoridade. Dispersos pelo sertão, os Índios nem se purificariam de superstições, nem deixariam de se guerrear e comer uns aos outros. Era preciso modificar o seu sistema social e econômico (grifo nosso) ${ }^{14}$.

Considerando que a colonização não poderia se dar pela simples exploração econômica ou destruição dos povos nativos, os aldeamentos desempenharam um papel estratégico neste processo : "Aqui no Brasil tratou-se desde o início de aproveitar o índio, não apenas para obtenção dele, pelo tráfico mercantil, de produtos nativos, ou simplesmente como aliado, mas sim como elemento participante da colonização" ". Como afirma Monteiro, "oferecendo um contraponto à dizimação deliberada praticada pela maioria dos colonos, os jesuítas buscaram controlar e preservar os índios através de um processo de transformação que visava regimentar o índio enquanto trabalhador produtivo"16.

A estratégia missionária adotada pelos jesuítas fazia parte de um projeto mais amplo definido pelo padre Manoel da Nóbrega em um documento que ficou conhecido como sendo seu "plano de colonização"17. Nóbrega defendia que a sujeição dos índios ao domínio lusitano era uma condição indispensável para que se conseguisse convertê-los ao cristianismo, argumentando que o

\footnotetext{
${ }^{13}$ BOM MEIHY, José Carlos Sebe. A presença do Brasil na Companhia de Jesus (15491649). Tese de doutoramento apresentada ao Departamento de História da FFLCH/USP. São Paulo : USP, 1975, p. 184.

${ }^{14}$ LEITE, História da Companhia de Jesus no Brasil, t. II, p. 42-43.

${ }^{15}$ PRADO JR., Formação do Brasil contemporâneo, p. 1197.

${ }^{16}$ MONTEIRO, John Manuel. Negros da terra : índios e bandeirantes nas origens de São Paulo. São Paulo : Companhia das Letras, 1994, p. 36. Esta posição é defendida também por Maria Regina Almeida, para quem os aldeamentos foram elementos fundamentais da política colonial ibérica. Cf. ALMEIDA, Maria Regina Celestino de. Metamorfoses indígenas : identidade e cultura nas aldeias coloniais do Rio de Janeiro. Rio de Janeiro : Arquivo Nacional, 2003.

${ }^{17}$ LEITE, História da Companhia de Jesus no Brasil, t. II, p. 114.
} 
consentimento gerado pelo medo não implicava em coerção, sendo um meio propício para possibilitar o trabalho missionário mediante a persuasão e a catequese $^{18}$. Para Nóbrega, a Coroa deveria repartir o serviço dos índios entre os colonos que ajudassem a conquistar e povoar as novas terras, combatendo por este meio a escravidão ilícita dos brasis e promovendo o enriquecimento dos próprios colonos e do monarca português. Quanto aos índios, afirmava o primeiro provincial jesuíta da América portuguesa,

A lei, que lhes hão de dar, é defender-lhes [de] comer carne humana e guerrear sem licença do Governador; fazer-lhes ter uma só mulher, vestirem-se, pois têm muito algodão, ao menos depois de cristãos, tirar-lhes os feiticeiros, mantê-los em justiça entre si e para com os cristãos; fazêlos viver quietos sem se mudarem para outra parte, se não for para entre cristãos; tendo terras repartidas que lhes bastem e com êstes Padres da Companhia para os doutrinarem ${ }^{19}$.

De certo modo, os aldeamentos serviam também aos colonos como reserva de mão de obra. $\mathrm{O}$ trabalho indígena podia ser recrutado em momentos de maior demanda dos engenhos, no litoral, ou na extração de minérios e condução de boiadas, no sertão. Ao recrutamento deveria corresponder um salário justo, embora geralmente isto não fosse respeitado. Aos poucos, os colonos passaram a tentar burlar de todas as formas o sistema. Paralelamente seguia-se a prática, tornada legal, de escravizar índios tomados em guerra justa ${ }^{20}$.

A partir do final do século XVI os jesuítas procuram trazer índios do "sertão" para as proximidades da cidade e vilas, de modo a compensar os decréscimos populacionais das aldeias ${ }^{21}$. No entanto, sendo o declínio demográfico um fator constante dos aldeamentos circunvizinhos às vilas coloniais, os missionários são levados a adentrar o sertão e estabelecer aldeamentos longe dos povoa-

\footnotetext{
${ }^{18}$ EISENBERG, As missões jesuíticas e o pensamento político moderno, p. 89-92.

${ }^{19}$ Carta de Nóbrega ao Provincial da Companhia de Jesus, 8 de maio de 1558. Publicado em LEITE, Serafim. Novas cartas jesuíticas : de Nóbrega a Vieira. São Paulo : Companhia Editora Nacional, 1940, p. 79.

${ }^{20}$ BEOZZO, José Oscar. Leis e regimentos das missões : política indigenista no Brasil. São Paulo : Loyola, 1983.

${ }^{21}$ POMPA, Religião como tradução : missionários, Tupi e Tapuia no Brasil colonial. Bauru : EDUSC, 2003, p. 316.
} 
dos coloniais, movimento intensificado no período após a ocupação holande$\mathrm{sa}^{22}$. Das aldeias fundadas pelos jesuítas ao redor da cidade de Salvador, apenas a do Espírito Santo, no Rio Joanes, sobreviveu até o século XVIII, tendo sido transformada em vila, em 1758. Como afirma Leite, o trabalho missionário se alargaria, a partir de então, "para os confins da civilização"23.

Até este momento, o trabalho de catequese e conversão dos povos nativos havia ficado quase inteiramente a cargo dos jesuítas. A atuação de outras ordens religiosas se daria a partir do início do século XVII, coincidindo com esta expansão da atividade missionária em direção ao sertão. Para Puntoni, esta "ocidentalização" da empresa missionária esteve relacionada diretamente com o fim da ocupação holandesa no nordeste e o interesse da Coroa portuguesa em estender o raio de ocupação do território colonial ${ }^{24}$. A ampliação da "fronteira missionária" e a atuação de diferentes ordens religiosas fizeram com que o Rei criasse em cada uma das principais capitanias uma Junta das Missões (Maranhão, 1655, Pernambuco, 1681, Bahia, 1702). O objetivo era “dotar o governo local de um mecanismo descentralizado do poder imperial capaz de interceder na resolução de conflitos e propor in loco medidas e políticas para as atividades missionárias e para o processo de ocupação do sertão" ${ }^{25}$. A idéia de que teria existido durante o século XVII um "ciclo missionário sertanejo", defendida por Hoornaert, é refutada por Puntoni, que enfatiza a estreita subordinação das ordens religiosas às diretrizes traçadas pelo Estado ${ }^{26}$.

Indo em direção ao sertão, os aldeamentos se chocariam com os criadores de gado e sertanistas, ao tempo em que grupos indígenas não falantes do tupi iam sendo contatados. Tais grupos, apelidados genericamente de tapuias, eram em sua maioria caçadores e coletores semi-nômades, mais avessos às trocas culturais e mais propensos à resistência $\operatorname{armada}^{27}$. A identificação e reconsti-

\footnotetext{
${ }^{22}$ Ibid., p.318; PUNTONI, Pedro. A guerra dos bárbaros : povos indígenas e a colonização do sertão nordeste do Brasil. São Paulo : EDUSP, 2002, p. 25.

${ }^{23}$ LEITE, História da Companhia de Jesus no Brasil, t. V, p. 269.

${ }^{24}$ PUNTONI, A guerra dos bárbaros, p. 71.

${ }^{25}$ Ibid., p. 73.

${ }^{26}$ Ibid., p. 73, nota 72 .

${ }^{27}$ PARAÍSO, Maria Hilda Baqueiro. De como se obter mão de obra indígena na Bahia entre os séculos XVI e XVIII. In: Revista de História. São Paulo, n. 129-131, ago-dez/1993 a ago-dez/1994, p. 194.
} 
tuição etnográfica das dezenas de etnias que foram genericamente retratadas ou referenciadas como "tapuia" mostra-se extremamente difícil, embora se possa afirmar, com segurança, o predomínio dos grupos Kariri e Payayá no sertão ao sul do Rio São Francisco ${ }^{28}$.

Em 1667, segundo Leite, o missionário João de Barros dá notícias promissoras das primeiras aldeias no sertão ${ }^{29}$. A partir de 1679 , de acordo com Pompa, as "aldeias dos tapuias" começam a aparecer nos "catálogos" jesuíticos ${ }^{30}$. Aos poucos, em meio a conflitos pela posse das terras e pelo controle sobre a população indígena aldeada (opondo missionários e colonos), a atividade jesuítica se consolida no sertão da Bahia e nas capitanias de Sergipe, Ilhéus e Porto Seguro, região missionária articulada em torno do Colégio da Bahia.

\section{Uma época de "reformas"}

A partir de 1751 tem início, na região norte da América portuguesa, uma nova política no tocante aos aldeamentos indígenas, os quais eram vistos como verdadeiras "empresas" cuja prosperidade provocava nos colonos uma oposição ferrenha às ordens religiosas e à catequese ${ }^{31}$. O objetivo era conter o "excessivo domínio" que os religiosos supostamente possuíam sobre as terras e as populações indígenas ${ }^{32}$. Em 1755 foram promulgadas duas Leis concedendo plena liberdade aos índios e tirando das mãos dos missionários a autoridade civil e religiosa sobre os aldeamentos, a qual lhes havia sido outorgada, depois

${ }^{28}$ DANTAS, Beatriz G., SAMPAIO, José Augusto L., CARVALHO, Maria Rosário G. de. Os povos indígenas no Nordeste brasileiro : um esboço histórico. In : CUNHA, Manuela Carneiro. História dos índios do Brasil. São Paulo : Companhia das Letras, 1992, p. 432. Como assinala Pompa, a noção de "tapuia" constrói-se associada à de "sertão", delineando um espaço específico da colonização onde a alteridade "bárbara" vai aos poucos sendo incorporada, em posição subalterna, ao universo colonial. Cf. POMPA, Religião como tradução, p. 229.

${ }^{29}$ LEITE, História da Companhia de Jesus no Brasil, t. V, p. 282-283.

${ }^{30}$ POMPA, Religião como tradução, p. 320.

${ }^{31}$ ALDEN, Dauril. Aspectos econômicos da expulsão dos Jesuítas do Brasil : Notícia preliminar. In : KEITH, H. e EDWARDS, S. F. Conflito e continuidade na sociedade brasileira. São Paulo : Civilização Brasileira, 1970.

${ }^{32}$ INSTRUÇÕES públicas e secretas para o governador do Estado do Grão Pará e Maranhão (1751). Publicado por AZEVEDO, João Lúcio de. Os jesuítas no Grão-Pará. Lisboa : Tavares, 1901, p. 351. Desnecessário dizer que as reformas aqui referidas coincidem com a ascensão de D. José I ao trono português e a nomeação de Sebastião José de Carvalho e Melo, futuro Marquês de Pombal, como poderoso ministro de Estado. 
de idas e vindas, pelo Regimento das Missões de $1686^{33}$. As aldeias indígenas seriam transformadas em vilas ou povoados, não mais sendo administradas pelas ordens religiosas. A estas, restaria o trabalho de enfrentar os sertões bravios em busca de povos nativos na tentativa de conduzi-los pacificamente para junto das povoações coloniais a fim de serem convertidos e doutrinados ${ }^{34}$. A publicação destas Leis se deu em 1757, ano em que foi também redigido o Diretório das Povoações dos Índios do Pará e Maranhão, propugnando uma série de medidas destinadas a melhor preparar os índios para assumirem o governo civil de suas aldeias ${ }^{35}$. Os objetivos básicos do Diretório eram criar um campesinato indígena integrado economicamente à sociedade colonial e tornar os índios veículos da colonização portuguesa ${ }^{36}$.

Estas medidas, estendidas para o conjunto da América portuguesa através de um "Alvará com força de Ley" datado de 8 de maio de 1758, seriam efetivadas na Bahia através de um conjunto de decretos e ordens régias mandadas executar por um Tribunal Especial do Conselho Ultramarino instituído por magistrados enviados de Lisboa e presidido pelo Vice-rei D. Marcos de Noronha, nas matérias civis, e pelo Arcebispo D. José Botelho de Matos, nas matérias pertinentes à religião ${ }^{37}$.

Incluindo as capitanias de Ilhéus, Porto Seguro e Sergipe, segundo informações de Caldas, reproduzidas por Vilhena, e de acordo também com os documentos consultados, apenas os aldeamentos jesuítas tornaram-se vilas, sendo onze

\footnotetext{
${ }^{33} \mathrm{Cf}$. BEOZZO, Leis e regimentos das missões.

${ }^{34}$ Lei de 6 de junho de 1755. Arquivo Público da Bahia (APEB). Seção Colonial e Provincial, série Ordens Régias. Livro 60, doc. 82. Também presente em : Collecção dos Breves Pontifícios e Leys Régias, que forão expedidas, e publicadas desde o anno de 1741 sobre a liberdade das Pessoas, Bens e Comercio dos Índios do Brasil. O exemplar consultado foi o da Divisão do Patrimônio Histórico e Cultural (antigo Arquivo Municipal), Salvador, Bahia. Livro 35.1. Transcrição.

${ }^{35}$ Cf. ALMEIDA, Rita Heloísa. O Diretório dos Índios. Brasília : Universidade de Brasília, 1997.

${ }^{36}$ DOMINGUES, Ângela. Quando os índios eram vassalos. Colonização e relações de poder no Norte do Brasil na segunda metade do século XVIII. Lisboa : Comissão Nacional para as Comemorações dos Descobrimentos Portugueses, 2000, p. 68.

${ }^{37}$ Arquivo Histórico Ultramarino. Documentos manuscritos avulsos da capitania da Bahia. Documento n. 3629 e anexos. Disponível em CD-ROM : Projeto Resgate de Documentação Histórica.
} 
no total $^{38}$. Coube a este mesmo Tribunal do Conselho Ultramarino erigir as vilas de Almeida e Benevente, na capitania do Espírito Santo ${ }^{39}$. As aldeias administradas por outras Ordens religiosas e por padres seculares não se tornaram vilas neste primeiro momento de aplicação da legislação pombalina, embora ela própria não fizesse distinção entre as aldeias dos jesuítas e as aldeias das demais Ordens religiosas.

O extenso relatório enviado a Lisboa pelo Tribunal do Conselho Ultramarino em 22 de dezembro de 1758 retrata com detalhes os primeiros encaminhamentos no sentido da adoção das medidas pertinentes à "secularização" das aldeias $^{40}$. A primeira questão que veio à baila, ao se reunirem os Conselheiros com o Vice-rei, foi a respeito do procedimento adequado para se erigir as vilas. O Conde dos Arcos propôs que se fizesse um questionário para levantar todas as informações necessárias de cada aldeia e que somente após este questionário ser trazido de volta ao Tribunal do Conselho se tomariam as resoluções específicas referentes a cada uma das novas vilas a serem "erigidas".

Na reunião seguinte foram aprovados "por votos conformes" os questionários e as sugestões que seriam dadas aos ministros designados para erigir as vilas. No entanto, o conselheiro José Mascarenhas argumentou que a diligência tomaria muito tempo, sendo as viagens pelo sertão difíceis e dispendiosas. Sugeriu que os ministros designados para as aldeias deveriam estabelecer de imediato as vilas, ao menos interinamente, apresentando depois ao Tribunal do Conselho o questionário já respondido. Argumentou que "a celeridade é quase sempre madrasta da justiça" e a demora podia trazer inconvenientes maiores, baseando este seu parecer no fato de que o atual monarca sempre realizava as coisas com admirável brevidade, ao contrário dos anteriores, que gastavam séculos para estabelecer coisas novas. Mascarenhas arrematou suas alegações alertando que, estando os jesuítas nas aldeias, haveria suspeitas de que o questionário não fosse respondido verdadeiramente, o mesmo não devendo ocorrer com a presença dos novos párocos, que não deviam ter a mesma ingerência no governo político, "pois de

\footnotetext{
${ }^{38}$ VILHENA, Luís dos Santos. A Bahia no século XVIII. Bahia : Itapuã, 1969, v. II, p. 460461; APEB, Seção Colonial e Provincial, maço 603, cadernos 14, 15 e 32.

${ }^{39}$ APEB, Seção Colonial e Provincial, maço 603, caderno 14.

${ }^{40}$ APEB, Seção Colonial e Provincial, maço 603, caderno 32. O documento se encontra publicado no volume XXVI dos Anais do Arquivo Público da Bahia, p. 5-45.
} 
outra forma seria se concorrer para o mesmo abuso que se queria evitar". O Tribunal, então, deliberou pela imediata secularização da aldeia do Espírito Santo, que ficava a poucas léguas da cidade, e que "depois de feito este estabelecimento se regularia o das mais aldeias por fórma de que cada Informante que a elas fosse mandado pudesse logo levar instruções e ir munido da jurisdição necessária para o completo estabelecimento delas" ${ }^{41}$.

Embora o próprio Mascarenhas tenha se oferecido para estabelecer a vila de Abrantes, na aldeia do Espírito Santo, foi designado para a tarefa o juiz de fora da cidade da Bahia, João Ferreira Bittencourt. A ordem foi dada a ele no dia 28 de setembro. Em 11 de outubro ele já apresentava ao Tribunal um completo relatório. Por proposta do Conde dos Arcos, passou-se uma provisão para dar ciência à Câmara de Salvador, pois o estabelecimento da nova vila implicava o desmembramento do território da cidade. A carta tem a data de 30 de setembro. Sendo passada como ordem régia dada através do Conselho Ultramarino, reproduz os argumentos expostos nas leis de 6 e 7 de junho de 1755 e no alvará de 8 de maio de 1758. Diz que o estabelecimento de vilas é o melhor meio de se civilizarem e poderem instruir os índios a utilizar da agricultura e comércio, e de mantê-los no pleno gozo da liberdade de suas pessoas, bens e comércio; e que "por ser presente que a Aldeia do Espírito Santo tem o número de vizinhos e a extensão preciza para o dito effeito S. Majestade foi servido ordenar ao Bacharel João Bittencourt estabelecer nela uma vila com o nome Nova Abrantes do Espírito Santo". O "registre-se" da câmara é datado de 3 de outubro ${ }^{42}$. Cartas semelhantes deveriam ser enviadas para aviso das respectivas Câmaras das quais as novas vilas se desmembrariam.

Com relação à conta, interrogatórios e documentos apresentados por Bittencourt, a dúvida maior dizia respeito à extensão de terras que deveriam pertencer à vila e aos índios. O Conselho sugeriu ao ministro que procurasse $\mathrm{o}$ Provincial dos jesuítas para que o mesmo apresentasse os títulos de posse das terras pertencentes aos índios. O Provincial alegou não ter encontrado nenhum "título" (documento ou certidão) no Colégio. O Conselho, informado, passou então uma provisão ordenando que o Provincial avisasse aos superiores de todas

\footnotetext{
${ }^{41}$ APEB, Seção Colonial e Provincial, maço 603, caderno 32.

${ }^{42}$ Anais do Arquivo Público da Bahia, volume XXVI, p. 1-2.
} 
as residências e missões que apresentassem imediatamente todos os documentos que fossem solicitados pelos ministros designados para estabelecer as vilas nas antigas aldeias. Uma outra ordem foi dada ao Provincial para que apresentasse os livros onde pudessem ser averiguados os bens pertencentes às igrejas das aldeias. Sem satisfazer inteiramente ao Conselho, o Provincial disse ter expedido ordem aos superiores das aldeias para que executassem as ordens régias ${ }^{43}$.

Em 16 de outubro o Tribunal do Conselho exigiu um parecer definitivo de Bittencourt quanto às terras a serem demarcadas para a nova vila. Bittencourt advogou a concessão de duas léguas de frente pelo litoral (até o Rio Joanes) e três de fundo, que parecia ser a única terra que os índios efetivamente tinham posse. Segundo Bittencourt, não havia títulos que comprovassem a doação de Mem de Sá de três léguas em quadra, que os índios alegavam a seu favor. Além disso, as cinco léguas quadradas seriam suficientes para que os 40 casais de índios da aldeia pudessem se sustentar, sem prejuízo dos moradores situados do outro lado do Rio Joanes, que haviam apresentado títulos válidos da posse de suas terras. Sobre umas terras confinantes pertencentes aos jesuítas, pareceu ao ministro ser conveniente tomá-la dos religiosos, pois o gado invadia as terras indígenas e destruía as lavouras. O Conselho decidiu concordar com o ministro, menos com respeito à terra dos jesuítas. O Conselheiro Manoel Estevão foi de voto contrário à demarcação das terras, alegando que a prioridade da posse das terras deveria caber aos índios, e não aos colonos ${ }^{44}$.

Mantendo interinamente o parecer do ministro, o Tribunal resolveu consultar o Rei acerca das questões sobre as quais não tinha havido consenso. Todas elas versavam sobre a questão das terras que deviam pertencer aos índios e à vila, demonstrando ser esta uma questão central no relacionamento entre os colonos e as populações indígenas naquela região. A aldeia havia sido fundada no segundo semestre de 1558 pelo P. João Gonçalves e o Ir. Antonio Rodrigues e não havia nela índios pagãos no século XVIII ${ }^{45}$. A posse das terras indígenas estava já assegurada e sua exploração feita por meio de arrendamento, tendo sido avaliadas como férteis e boas para o cultivo de mandioca, feijão, algodão, mamona e melancia ${ }^{46}$. Não se tratava de região fornecedora de açúcar, tabaco, fa-

\footnotetext{
${ }^{43}$ APEB, Seção Colonial e Provincial, maço 603, caderno 32.

${ }^{44}$ Idem.

${ }^{45}$ LEITE, História da Companhia de Jesus no Brasil, t. II, p. 53.
} 
rinha de mandioca ou madeiras. O estado geral da aldeia era de muita pobreza : "Todas as casas eram de barro batido, cobertas de palha. Não havia uma só construção de pedra e cal, tijolos e telhas. A igreja e a casa dos padres jesuítas - o hospício - estavam em ruínas" ${ }^{\star 47}$. Os únicos criadores de gado citados no relatório do Tribunal do Conselho Ultramarino eram os próprios jesuítas ${ }^{48}$.

Com o estabelecimento ou "ereção" de Abrantes, define-se o modo como se havia de proceder nas demais. Provavelmente não houve aplicação fidedigna deste modelo nos diferentes contextos em que as demais aldeias estavam inseridas, mas o fato de o Conselho acreditar que isto fosse possível revela suas intenções e seu pensamento em torno dos elementos definidores da nova política colonial em vigor.

Ainda no final de 1758 foram designados ministros para as demais aldeias, o que consta do relatório de 22 de Dezembro e de documentos avulsos. O ouvidor e corregedor da comarca da Bahia, Luiz Freire de Veras, ficou encarregado das aldeias de Santo André, Nossa Senhora das Candeias e Nossa Senhora da Escada, situadas na Capitania de Ilhéus. Para a aldeia de Nossa Senhora da Conceição, na mesma Capitania, não se designou ministro. O juiz de fora da vila de Cachoeira, José Gomes Ribeiro, ficou responsável pela aldeia de Natuba, localizada no sertão da Bahia. O ouvidor e corregedor da comarca de Sergipe foi encarregado das outras três aldeias de índios Kiriri situadas na mesma região, a saber, Saco dos Morcegos, Canabrava e Geru (localizada na Capitania de Sergipe d'El Rei). O capitão-mor de Porto Seguro, Antônio da Costa Souza, e o ouvidor Manoel da Cruz Freire, ficaram responsáveis pelas duas aldeias administradas pelos jesuítas na região : a aldeia de São João e a aldeia do Espírito Santo. O ouvidor e corregedor da comarca da capitania do Espírito Santo, Francisco de Salles Ribeiro, foi também designado pelo Tribunal do Conselho, estabelecido na Bahia, para transformar em vilas as aldeias de Reritiba e Reis Magos ${ }^{49}$.

\footnotetext{
46 TAVARES, Luís Henrique Dias. Aspectos sócio-econômicos das vilas criadas em 1758. In: Revista do Instituto Histórico e Geográfico da Bahia, n. 83, p. 89-93, 1961/1967, p. 90. ${ }^{47}$ Ibid., p. 91.

${ }^{48}$ Infelizmente, não consegui descobrir qual foi a resolução final tomada pelo Rei nesta matéria, mas provavelmente o monarca tenha seguido a deliberação do Conselho e deixado de posse de suas terras tanto os colonos quanto os jesuítas, pelo menos até a sua expulsão no ano seguinte.

${ }^{49}$ APEB, Seção Colonial e Provincial, maço 603, cadernos 11, 15, 32.
} 
As instruções dadas a estes ministros indicam certa flexibilização do costume português de modo a compensar o despreparo dos índios para o regime civil. Foi permitida a eleição de camaristas analfabetos, para que não se tornasse necessário recorrer a portugueses. Apenas o escrivão, por razões óbvias, tinha que ser alfabetizado, apto na inteligência e conhecimento dos procedimentos processuais, devendo-se escolher de preferência um português casado com índia, caso não houvesse nenhum índio capaz de exercer o cargo. Devia haver um juiz e três vereadores, um alcaide e um porteiro. $\mathrm{O}$ ministro providenciaria uma casa que servisse de cadeia e outra para as conferências da câmara e do juiz, não devendo ser usada a casa do pároco. Um pelourinho seria levantado, em lugar que servisse de praça ${ }^{50}$.

Foram também enviados questionários para serem preenchidos e devolvidos ao Tribunal do Conselho, como forma de avaliar se a diligência havia sido realizada a contento ou se convinha que algo fosse mudado. As questões versavam sobre o estado em que se encontrava a aldeia, quantos índios a habitavam, se eram ricos e tinham boas casas, se falavam a língua portuguesa, se sabiam ler ou escrever, se havia oficiais mecânicos e de que ofícios, como se alimentavam e se vestiam, em que camas dormiam, a que nação pertenciam, se exerciam algum tipo de comércio ou possuíam rendimentos, se possuíam gados, individualmente ou em comum, qual o proveito que se poderia esperar com a transformação daquela aldeia em vila ${ }^{51}$.

O interesse pelo aspecto "econômico" sobressai nestes questionários e também nas questões referentes à atuação dos missionários junto aos índios. O Tribunal demandava informações sobre o tamanho da Igreja e da casa onde até então tinham residido os missionários, se os índios davam ofertas ou tinham alguma despesa com os serviços religiosos, se os missionários tiravam algum rendimento da igreja, se possuíam terras ou gado, se alguém ou algum missionário se servia dos índios como escravos, ou se alguém se aproveitava do salário ou do rendimento dos índios ${ }^{52}$.

\footnotetext{
${ }^{50}$ APEB, Seção Colonial e Provincial, maço 603, caderno 15.

${ }^{51}$ APEB, Seção Colonial e Provincial, maço 603, caderno 21.

${ }^{52}$ Idem.
} 
De certo modo, a resposta a esta excessiva preocupação do governo com o suposto aparato político e econômico das missões jesuíticas já havia sido dada pelo próprio conselheiro ultramarino José Mascarenhas Coelho de Mello. Segundo ele, as aldeias eram "cousa pobríssima e de pequeníssima esperança, porque a terra não he tão inculta e ingrata como os seus habitantes". Com respeito aos jesuítas, asseverava : "estão no mayor socego e humildade que he possível, bem poderá ser isto afectado, porém nesta capitania não pode haver temor de que facão a menor perturbação no Estado, pois não tem hoje, partido nem forças para isso" 53 .

\section{Párocos ou missionários?}

Embora as Leis de 1755 e o Diretório de 1757 aparentemente visassem apenas remover a administração temporal dos missionários sobre os índios aldeados, guardando-lhes a assistência espiritual, normas específicas indicavam que as aldeias fossem transformadas não apenas em vilas, mas também em paróquias, entregando-se o governo temporal a autoridades civis eleitas pelos próprios índios e o governo espiritual a párocos do hábito de São Pedro (padres seculares) ${ }^{54}$.

Em carta dirigida ao Arcebispo da Bahia, datada de 8 de maio de 1758, o Rei trata diretamente deste assunto, mencionando explicitamente as aldeias administradas pelos jesuítas. Orienta o Arcebispo a erigir vigararias nas antigas missões, referindo-se aos índios como paroquianos. Diz que a assistência espiritual concedida pelos missionários aos índios havia sido permitida interinamente, enquanto o clero secular não pudesse prestá-la, mas que, estando informado que a arquidiocese já contava com o suficiente número de párocos, havia por bem dar como terminado o período desta "interina irregularidade"

\footnotetext{
${ }^{53}$ Carta ao Secretário de negócios ultramarinos, 22 de dezembro de 1758. Publicado em ACCIOLI, Ignácio e AMARAL, Braz do. Memórias históricas e políticas da província da Bahia. Salvador : Imprensa Oficial, 1919-1940, vol. V, p. 556-557.

${ }^{54} \mathrm{O}$ parágrafo quarto do Diretório encarregava a cristianização dos índios "à exemplar vigilância do Prelado desta Diocese", ou seja, outorgava o controle do clero secular sobre o regular, mas não implicava necessariamente na expulsão dos missionários, desde que estes se submetessem à autoridade episcopal. Cf. ALMEIDA, O Diretório dos Índios e BEOZZO, Leis e regimentos das missões.

${ }^{55}$ Carta régia dirigida ao Arcebispo da Bahia. In : ACCIOLI, Ignácio e AMARAL, Braz do. Memórias históricas e políticas da província da Bahia. Salvador : Imprensa Oficial, 1919-1940. Vol. V, p. 561-562.
} 
Conquanto pudesse ter sido uma medida extremamente hostil aos jesuítas e ao trabalho missionário, a secularização dos aldeamentos missionários contribuiu para o aumento do número de paróquias no sertão da Bahia, a reunião de pequenas aldeias prestes a desaparecer, a assistência às populações ao derredor das aldeias, o aumento do poder de intervenção do Arcebispo ${ }^{56}$.

O clero regular havia sempre se antecipado ao secular em regiões recentemente conquistadas ou por conquistar, recebendo por isto autoridade especial para organização de paróquias nestas regiões ${ }^{57}$. Apesar das críticas a esta situação, a dificuldade em manter nas regiões de missão um clero secular zeloso e interessado, ao lado da recusa quanto à formação de um clero nativo (associado a questões políticas e raciais), reforçavam a tendência das ordens regulares para se aproximar do poder e afirmar seu senso de superioridade organizacional e moral ${ }^{58}$.

Segundo o cronista José Caeiro, espécie de porta-voz dos jesuítas após a expulsão, os párocos designados para as antigas aldeias as abandonaram em pouco tempo ${ }^{59}$.É bem possível. Sabe-se da pouca assistência religiosa dispensada à gente do sertão. Em 1798 o Cônego Antônio Borges Leal dá informação de doze freguesias que "ou contavam inteiramente com população indígena ou ajuntavam a esta alguns portugueses" ${ }^{60}$. A localização de quase todas coincide com os antigos aldeamentos jesuítas : cinco no litoral sul (antigas capitanias de Ilhéus e Porto Seguro), uma no litoral norte, cinco no sertão de baixo e uma no sertão de cima. Como diz Costa e Silva, estas freguesias assinalavam um momento de transição, onde não mais existia a missão, "mas longe andava a freguesia sucedânea de se ombrear com aquelas de larga tradição e mais bem situadas na geografia" ${ }^{61}$. A inserção do índio na vida religiosa comum proposta pela legislação pombalina carecia de mais tempo ou empenho. Não obstante, ainda que paulatinamente, o clero diocesano ia apascentando também este rebanho, sem com isso conseguir evitar que no século XIX o sertão da Bahia reclamasse novamente missionários, atendendo a isto os capuchinhos ${ }^{62}$.

\footnotetext{
${ }^{56}$ SILVA, Cândido da Costa e. Os segadores e a messe, p. 56-57.

${ }^{57}$ BOXER, Charles. A igreja e a expansão ibérica. Lisboa : Edições 70, 1989, p. 85.

${ }^{58}$ Ibid., p. 86-87.

${ }^{59}$ CAEIRO, José. Jesuítas do Brasil e da Índia na perseguição do Marquês de Pombal (século XVIII). Bahia : Escola Tipográfica Salesiana, 1936, p. 53-55.

${ }^{60}$ SILVA, Cândido da Costa e. Os segadores e a messe, p. 76.

${ }^{61}$ Ibid., p. 77.

${ }^{62}$ Ibid., p. 81.
} 
Os missionários, entretanto, não estariam completamente excluídos da nova política colonial proposta no século XVIII. A lei de 6 de junho de 1755 determinava que os missionários continuassem atuando junto aos índios que vivessem dispersos, nos sertões, aldeando-os e instruindo-os na religião cristã, buscando persuadi-los a "descerem" para as povoações indígenas recém transformadas em vilas. No entanto, mesmo junto a estas populações pagãs e remotas caberia ao Governador e Capitão Geral "hum exacto cuidado na instrucção civil dos referidos Índios, que forem aldeados nos Sertoens, fazendolhes conservar as liberdades das suas pessoas, bens, e commercio"63.

\section{Projeto de civilização ou antijesuitismo?}

No contexto das medidas que visavam a "secularização" das missões se processa a expulsão definitiva dos jesuítas do Reino e dos domínios ultramarinos lusitanos. De acordo com a própria Lei de 3 de setembro de 1759, a questão dos aldeamentos teria desempenhado um papel central na oposição crescente entre o governo e os missionários ${ }^{64}$. Ratificando os termos expressos em um virulento panfleto anti-jesuíta denominado Relação Abreviada da República que os religiosos jesuítas das Províncias de Portugal e Espanha estabeleceram nos Domínios Ultramarinos das duas Monarquias e da Guerra, que nelas têm movido e sustentado contra os Exércitos Espanhóis e Portugueses, publicada em 1757, a Lei responsabilizava os jesuítas pela guerra contra os guarani das sete missões acusando-os de projetar um verdadeiro império que, em pouco tempo, seria superior "a todas as forças da Europa unidas"

Embora tivessem cumprido um papel político e econômico fundamental na formação colonial brasileira, os aldeamentos missionários ingressaram na segunda metade do século XVIII sob suspeita de fazerem parte de um amplo esquema de oposição ao Estado e enriquecimento ilícito das ordens religiosas. Os termos em que estavam colocadas as coisas na Relação Abreviada revela-

\footnotetext{
${ }^{63}$ APEB, Colonial e Provincial, Ordens régias, livro 60, doc. 82. Lei de 6 de junho de 1755 (anexo). ${ }^{64}$ COLEÇÃO dos Breves Pontifícios e Leis Régias. Divisão do Patrimônio Histórico e Cultural (antigo Arquivo Municipal), Salvador, Bahia. Livro 35.1. Transcrição. Publicado também em ACCIOLI, Ignácio e AMARAL, Braz do. Memórias históricas e políticas da província da Bahia, vol. V, p. 546-548.

${ }^{65}$ Idem.
} 
vam um rompimento definitivo entre os jesuítas e o Estado, antes mesmo que se decretasse a expulsão. $\mathrm{O}$ desfecho deste conflito viria após o atentado sofrido pelo monarca português em 3 de setembro de 1758, pelo qual os jesuítas seriam igualmente responsabilizados. A partir de então, as alegações quanto à suposta má conduta dos jesuítas nos aldeamentos do novo mundo seriam lugar para acusações diretas de traição e tentativa de regicídio, radicalizando a postura da Coroa. Os jesuítas que estavam na Bahia seriam conduzidos para o Reino como criminosos, reclusos inicialmente nas dependências do Colégio e, depois, no Noviciado da Jequitaia, situado à beira-mar, de onde partiriam para a prisão e o degredo ${ }^{66}$.

Buscar entender a atitude do Estado português perante os aldeamentos e as ordens religiosas no século XVIII como uma simples oposição entre política e religião oblitera o verdadeiro objeto desta disputa. De fato, política e religião não estavam em lados opostos. O próprio aldeamento, tal como definido no Regimento de 1686 e mesmo no Diretório de 1757 apresenta-se como expressão da "simbiose entre o espiritual e o temporal" que caracterizou a colonização desde o século XVI : "Embora a lei propugnasse a completa separação entre as esferas temporal e espiritual, o que se pretendia era a atuação conjunta e consensual" ${ }^{\prime 67}$.

Da perspectiva defendida pelos jesuítas, e até então compartilhada pela Coroa, a conversão seria o mais eficaz instrumento de "civilização" dos costumes e inserção dos gentios no "grêmio da igreja". Antes que "segregar" ou "dispersar", os jesuítas reuniam e preparavam as populações indígenas para se inserirem na sociedade colonial, embora esta inserção se desse quase sempre na forma da prestação de serviços aos moradores e à Coroa e através da participação em expedições militares, sobretudo as famosas "jornadas do sertão" que encheram o século XVII de confrontos, no interior da Bahia, com os povos qualificados como "tapuias" 68 .

Em suas Notícias sobre a Capitania da Bahia, de 1759, por exemplo, o engenheiro José Antonio Caldas argumenta que o acentuado declínio do número

${ }^{66}$ Cf. SANTOS, Fabricio Lyrio. Te Deum laudamus : A expulsão dos jesuítas da Bahia (1758-1763), Salvador, UFBA, 2002 (Dissertação de mestrado), especialmente o capítulo 4. Veja também COSTA, Marcus de Noronha da. A prisão e seqüestro dos padres da Companhia de Jesus na Baía pelo Vice-rei, o VI ${ }^{\circ}$ Conde dos Arcos. In : Anais do IV Congresso de História da Bahia, v. 1, Salvador : IGHBa ; Fundação Gregório de Mattos, 2001.

${ }^{67}$ DOMINGUES, Quando os índios eram vassalos, p. 168.

${ }^{68}$ Cf. PUNTONI, A guerra dos bárbaros. 
de missões em toda a capitania da Bahia havia sido causado pelo uso da mão de obra indígena, pelos sertanistas, nas entradas em busca das minas de ouro, "por que servindose os viandantes dos Índios por estipêndios, q lhes contribuirão para conduzirem as boyadas de gado de hum e outro gênero, forão ficando diminutas de tal sorte, que chegarão a dezertar Aldeas inteiras" ${ }^{69}$.

O suposto "poder político e econômico" acumulado pelos jesuítas a partir dos aldeamentos, se realmente existia, era um poder exercido em nome do Estado e sintonizado com os interesses mais amplos da política colonial ${ }^{70}$. Como argumentamos no início, a cumplicidade entre o poder "espiritual" e o poder "temporal" era um elemento fundamental do plano missionário traçado pelos jesuítas no contexto do padroado ultramarino. Como afirma Maria Regina Almeida, "os aldeamentos não foram autônomos em relação ao sistema colonial nem tampouco simples espaço cristão construído pelos jesuítas" "71 . Ao contrário do que afirma Prado Jr., a política pombalina (e, consequentemente, a expulsão dos jesuítas) não refletia "o interesse geral da colonização portuguesa no Brasil acima dos interesses particulares", mas, sim, o interesse específico de uma época onde a referida "simbiose do espiritual e do temporal" passou a ser redimensionada ${ }^{72}$.

Este redimensionamento do papel da religião e do lugar que ela deveria ocupar na política colonial não deve ser confundido com qualquer tentativa de abolição do catolicismo. Atendo-nos especificamente à questão dos aldeamentos indígenas, cabe notar que a "civilização" proposta era vista tanto como um "fim" a ser buscado em benefício do Estado quanto como um "meio" para se expandir a religião. No Alvará de 8 de maio de 1758, por exemplo, se afirma que a liberdade concedida aos índios era o "único e adequado meyo" para civilizálos "e attrahillos (...) para o grêmio da Santa Madre Igreja"73 . Os interesses políticos e econômicos em jogo - de resto, presentes desde o início da colonização - não excluíam a necessária conversão dos gentios ao catolicismo. A

\footnotetext{
${ }^{69}$ CALDAS, José Antônio. Noticia geral de toda esta Capitania da Bahia desde o seu descobrimento até o presente ano de 1759. In : Revista do Instituto Histórico e Geográfico da Bahia, 57, 1ª parte, 1931, p. 36.

${ }^{70}$ ALMEIDA, Metamorfoses indígenas, p. 82.

${ }^{71}$ Ibid., p. 136.

${ }^{72}$ PRADO JR. Formação do Brasil contemporâneo, p. 1199.

${ }^{73}$ APEB, Colonial e Provincial, Ordens régias, livro 60, doc. 82.
} 
religião, "relegada para o meio dos outros elementos da sociedade civil", continuaria a se fazer presente na política colonial, embora não mais com a marcante presença dos jesuítas.

\section{Bibliografia e Fontes Impressas}

ABREU, João Capistrano de. Capítulos de história colonial (1500-1800). Rio de Janeiro : Sociedade Capistrano de Abreu, 1936.

ACCIOLI, Ignácio e AMARAL, Braz do. Memórias históricas e políticas da província da Bahia. Salvador : Imprensa Oficial, 1919-1940. 6 v.

ALDEN, Dauril. Aspectos econômicos da expulsão dos Jesuítas do Brasil : Notícia preliminar. In : KEITH, H. e EDWARDS, S. F. Conflito e continuidade na sociedade brasileira. São Paulo : Civilização Brasileira, 1970.

ALMEIDA, Maria Regina Celestino de. Metamorfoses indígenas : identidade e cultura nas aldeias coloniais do Rio de Janeiro. Rio de Janeiro : Arquivo Nacional, 2003.

ALMEIDA, Rita Heloísa. O Diretório dos Índios. Brasília : Universidade de Brasília, 1997.

AZEVEDO, João Lúcio de. Os jesuítas no Grão-Pará. Lisboa : Tavares, 1901.

BEOZZO, José Oscar. Leis e regimentos das missões : política indigenista no Brasil. São Paulo, Loyola, 1983.

BOM MEIHY, José Carlos Sebe. A presença do Brasil na Companhia de Jesus (1549-1649). Tese de doutoramento apresentada ao Departamento de História da FFLCH/USP. São Paulo : USP, 1975.

BOXER, Charles. A igreja e a expansão ibérica. Lisboa : Edições 70, 1989.

CAEIRO, José. Jesuítas do Brasil e da Índia na perseguição do Marquês de Pombal (século XVIII). Bahia : Escola Tipográfica Salesiana, 1936.

CALDAS, José Antônio. Noticia geral de toda esta Capitania da Bahia desde o seu descobrimento até o presente ano de 1759. In : Revista do Instituto Histórico e Geográfico da Bahia, 57, $1^{\text {a }}$ parte, 1931.

COLEÇÃO dos Breves Pontifícios e Leis Régias. Divisão do Patrimônio Histórico e Cultural (antigo Arquivo Municipal). Salvador, Bahia. Livro 35.1. Transcrição.

COSTA, Marcus de Noronha da. "A prisão e seqüestro dos padres da Companhia de Jesus na Baía pelo Vice-rei, o VI ${ }^{\circ}$ Conde dos Arcos". In : Anais do IV Congresso de História da Bahia, v. 1, Salvador : IGHBa; Fundação Gregório de Mattos, 2001. 
DANTAS, Beatriz G., SAMPAIO, José Augusto L., CARVALHO, Maria Rosário G. de. Os povos indígenas no Nordeste brasileiro : um esboço histórico. In : CUNHA, Manuela Carneiro (org.). História dos índios do Brasil. São Paulo : Companhia das Letras, 1992.

DIRECTORIO, que se deve observar nas povoaçõens dos Índios do Pará, e Maranhão, enquanto Sua Magestade não mandar o contrário. Publicado em : ALMEIDA, Rita Heloísa. O Diretório dos Índios. Brasília : Universidade de Brasília, 1997.

DOMINGUES, Ângela. Quando os índios eram vassalos. Colonização e relações de poder no Norte do Brasil na segunda metade do século XVIII. Lisboa : Comissão Nacional para as Comemorações dos Descobrimentos Portugueses, 2000.

EISENBERG, José. As missões jesuíticas e o pensamento político moderno : encontros culturais, aventuras teóricas. Belo Horizonte : Editora UFMG, 2000.

FREYRE, Gilberto. Casa-Grande e Senzala. Formação da família brasileira sob o regime da economia patriarcal. In : Intérpretes do Brasil. $2^{\mathrm{a}}$ ed. Rio de Janeiro : Nova Aguilar, 2002.

HOORNAERT, Eduardo et al. História da Igreja no Brasil : ensaio de interpretação a partir do povo. Primeira época. $4^{\text {a }}$ ed. Petrópolis : Vozes, 1992.

INSTRUÇÕES públicas e secretas para o governador do Estado do Grão Pará e Maranhão. Publicado em : AZEVEDO, João Lúcio de. Os jesuítas no GrãoPará. Lisboa : Tavares, 1901.

LEITE, Serafim. História da Companhia de Jesus no Brasil, Rio de Janeiro : Instituto Nacional do Livro, 1938-1950. $10 \mathrm{v}$.

LEITE, Serafim. Novas cartas jesuíticas : de Nóbrega a Vieira. São Paulo : Companhia Editora Nacional, 1940.

MONTEIRO, John Manuel. Negros da terra : índios e bandeirantes nas origens de São Paulo. São Paulo : Companhia das Letras, 1994.

NEVES, Luis Felipe Baêta. O Combate dos soldados de Cristo na terra dos papagaios. Rio de Janeiro : Forense-Universitária, 1978.

PARAÍSO, Maria Hilda Baqueiro. De como se obter mão de obra indígena na Bahia entre os séculos XVI e XVIII. In : Revista de História. São Paulo, n. 129-131, ago-dez/1993 a ago-dez/1994.

POMPA, Religião como tradução : missionários, Tupi e Tapuia no Brasil colonial. Bauru, SP : EDUSC, 2003. 
PRADO JR., Caio. Formação do Brasil contemporâneo : Colônia. In : Intérpretes do Brasil. $2^{\mathrm{a}}$ ed. Rio de Janeiro : Nova Aguilar, 2002.

PUNTONI, Pedro. A guerra dos bárbaros : povos indígenas e a colonização do sertão nordeste do Brasil. São Paulo : EDUSP, 2002.

SANTOS, Fabricio Lyrio. Te Deum laudamus : A expulsão dos jesuítas da Bahia (1758-1763.). Dissertação de Mestrado. Salvador, UFBA, 2002.

SILVA, Cândido da Costa e. Os segadores e a messe : o clero oitocentista na Bahia. Salvador : SCI; EDUFBA, 2000.

TAVARES, Luís Henrique Dias. Aspectos sócio-econômicos das vilas criadas em 1758. In: Revista do Instituto Histórico e Geográfico da Bahia, n. 83, p. 8993, 1961/1967, p. 90.

VILHENA, Luís dos Santos. A Bahia no século XVIII. Bahia : Itapuã, 1969. 3 v. 